\title{
A Study on the Quality Factors of Brand Culture and Its Transmission Path-Taking Eral Group Corporation As an Example
}

\author{
Wu Zhixin Dr./ associate professor \\ Associate Dean of Business Administration College \\ Zhejiang University of Finance \& Economics Dongfang College \\ No. 2nd, Yangshan Road, Haining Town, Zhejiang, China 314408
}

\begin{abstract}
Brand culture connotation enhances the brand's value-added ability and competitiveness. On the basis of clarifying brand concept and brand culture, this paper probes into the most important quality factors in the brand culture elements, analyzes the importance of quality to the brand, and expounds the communication channels and routes of brand culture from enterprises to consumers with the Internet thinking. This paper takes Eral Group as an example and carries out surveys. On the basis of survey data, this paper, combining relevant theories, carries out case analysis.
\end{abstract}

Keywords-Brand; Brand culture; Internet of Things thinking; Advertising path

\section{ANALYSIS ON BRAND-RELATED CONCEPT}

\section{A. Brand definition.}

The word brand was first found in the ancient Norwegian. The original meaning of "brand" refers to the use of livestock, such as burning the mark as a private asset. It reflects the deep impression the brand has formed in the minds of consumers. In ancient Chinese, the meaning of "product" includes standard, variety, quality, grade and so on. And from the "product" of the composition of the word, the representative of the public taste and evaluation, which is now we often say word-of-mouth, therefore, the product is the intrinsic meaning of the brand, reflecting the consumer of the quality of the goods and their grade judgment. "Card "is intended to do the board of signs, extended to the name of the product, it can be understood as the external name and logo for the consumer to identify, it is the manifestation of the brand. In the Oxford Dictionary, the brand is interpreted as" to prove ownership, as a sign of quality or other uses ", with the business competition and the changes in the mode of retail trade, The meaning of brand is also becoming richer, the brand in the modern sense refers to a series of names, symbols, symbols, logos and their combinations which are stipulated by enterprises for their products or services and can be identified and selected by consumers.

The composition of the brand is divided into two major systems. A language system, you can address the name of the brand, such as: Eral. The second is the identification system. That is, in addition to the words to address the brand name, including symbols, patterns, colors, shapes, design and so on. Such as "eral" English alphabet signs, all belong to the brand logo.

Eral was founded in 1997, is focused on the young women's clothing brand, by 35 of the domestic first-line star in pursuit of great love. As the most fashionable brand of China down jacket Eral has original four-layer structure lock velvet patented technology, more than 3,000 Chinese stores, becoming the leading brand of female down jacket on line, is committed to build down jacket, home textiles, women's wear, children's clothing as one of the world-renowned fashion group!

Eral Group's icon, is used in English letter eral to describe, eral from the Japanese pronunciation, えらい (Great o Muhammad), the expression means "very great," "very big", "very strong" meaning. This is highly relevant to the company's core concepts of "salute to Fashion" and "Live for fashion" .A good icon can well explain the meaning of a brand.

\section{B. The cultural attribute of the brand}

The brand itself is a kind of meta culture with cultural attributes. On the one hand, the brand is the product of the combination of spirit and material, symbol and entity. Is the result of the combination of culture and product. On the other hand, culture is the connotation and life of the brand. Culture must permeate and fill in, and play an irreplaceable role, any brand, as long as can survive, there must be a certain cultural elements as a support, therefore, all brands have their corresponding cultural connotations. However, the brand in the cultural connotation of the thickness of the diversity, the brand with deep cultural background can bring the material satisfaction to the consumers while enhancing its spiritual enjoyment, for example, Eral company's cultural background can be said to be higher than Boston, Snow fly and other brands, in the fierce market competition environment, The brand has surpassed the product to become the enterprise market symbol is one of the most important intangible assets, and products are constantly changing, technology has been phased out of different, cultural heritage of the brand is the rapid occupation of the market and maintain market share of capital. Therefore, the culture and the brand are closely related, the brand belongs to the category of cultural value. Then, how 
to enhance the brand culture, how to make the brand of this meta culture is a combination of aesthetic, value, innovation and other characteristics of the brand culture. What is the formation path of brand to brand culture? This is a problem that every enterprise must focus on and solve.

\section{ANALYSIS ON BRAND CULTURE DEFINITION}

American historian David Kiln Landers wrote in a book: "If economic development has given us any enlightenment?" That is, culture is an important factor, cultural management in the western developed countries have developed more mature. The trend of the blending of culture and economy is more and more obvious. China has a long history and profound culture, how to use Chinese traditional culture to endow the brand with profound and novel implication, so as to enhance the brand value-added, enhance the national characteristics and competitiveness of the brand, has become the strategic problem of brand management.

Zhou Zhaoqing (2002) thinks that: Brand culture is the cultural characteristics of the brand in the precipitation, including brand management activities in all cultural phenomena. Zhu Li (2005) points out: Brand culture is the represents of the values such as the benefit cognition, the emotion attribute, the cultural tradition and the individuality image. Zhou Daqing (2009) thinks: Brand Culture embodies a brand personification of a cultural phenomenon. Brand culture and corporate culture, corporate philosophy are closely related to corporate culture and corporate philosophy in the brand embodiment. This article defines the brand culture as follows: brand culture is a series of brand-related language, aesthetic taste, values, consumer customs, ethics, lifestyle and other combinations, is the organic integration of brand and culture, from the perspective of communicators. Brand culture is a crystallization in the brand business philosophy and corporate culture embodiment. From the recipient's point of view, the brand culture of the audience is the vast number of consumers. The emotional distance between the brand and consumers increase the psychological satisfaction of consumers. Brand culture is embedded in the innermost brand, but also embodied in the various components of the brand.

\section{ANALYSIS ON QUALITY FACTORS OF BRAND CULTURE}

Quality factor analysis. Quality is the foundation of the brand. Any brand that can stand the test of time, its behind all have good product quality as a solid backing. Quality is also the external embodiment of brand culture. Building brand culture and shaping the image of the brand depend on highquality. Especially with the rapid development of information transmission channels such as network media and the increasing awareness of consumer self-protection. Product quality has aroused widespread concern and high attention of the community. Only the enterprise is committed to improving product quality in order to survive and develop in the fierce market competition. It can be said that no good product quality, a good brand is mirrors. For modern enterprises, quality not only contains product quality, but also contains the service in the process of product sales. Service quality is beginning to play more and more important role in the process of enterprise brand culture construction. The social public relies on the experience and evaluation of enterprise products and service quality. The establishment of the brand awareness will be the quality of recognition and trust gradually transferred to the abstract brand. Thus building a good brand image of products, so for the product, the quality is the soul brand.

The structural characteristics of quality factor culture consist of its material level, behavioral level, the system level and the morals stratification plane, these four levels together form the quality cultural pyramid according to the order from the low to the high, is consistent with the cultural change resistance characteristic, the quality cultural transformation resistance characteristic from the material level to the morals level enhances gradually, as shown in table 1.Among them, the material level and the behavior level have the high susceptibility, belong to the shallow level in the quality culture, but the system level and the morals stratification plane has the low susceptibility, belongs to the quality culture deep level.

TABLE I. STRUCTURAL FEATURES AND COMPONENTS OF QUALITY FACTOR OF CULTURE

\begin{tabular}{|c|c|c|}
\hline Level & Content & How easy it is to change \\
\hline 1 & Moral dimension & $\begin{array}{c}\text { Change the confrontation, the hardest level } \\
\text { to change }\end{array}$ \\
\hline 2 & Institutional level & Deeper level, more difficult to change \\
\hline 3 & Behavioral level & Lighter level, easier to change \\
\hline 4 & Material level & Easy to detect, easy to change \\
\hline
\end{tabular}

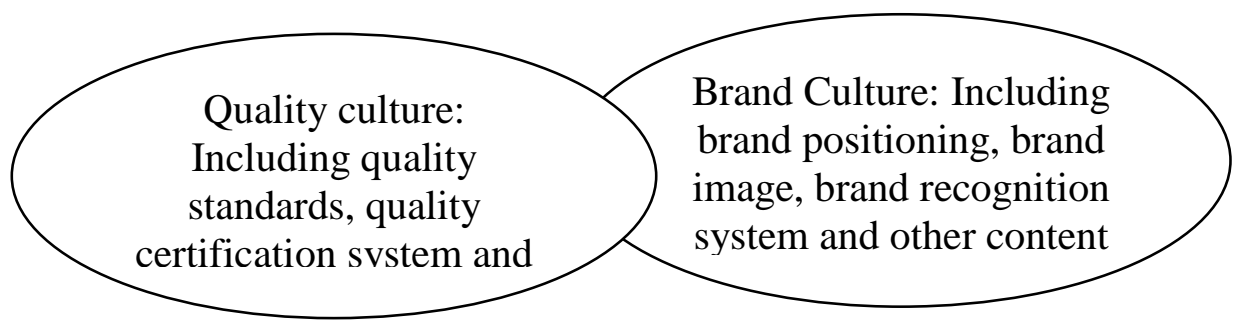

Fig. 1. The relationship between quality culture and brand culture 


\section{ANALYSIS ON THE ROUTE OF BRAND CULTURE TRANSMISSION BASED ON INTERNET THINKING}

The charm of the brand first lies in the excellent quality of the products. Based on the brand market positioning and product concept, the enterprise needs to be injected with the core values and cultural connotation. Reasonable integration, deduction, extension and expansion become the whole with brand harmony. Both of the above brand cultural elements of the brand for the product have given a rich cultural implication. It can touch the consumer from the cultural emotion and lead to the production of the consumption behavior. How to explain the brand culture more clearly, combine it with the scientific market culture operation mechanism effectively make the enterprise's brand communication embody the profound cultural implication.

In the choice of brand culture communication channel, there are mainly two kinds of modes: traditional media, including TV, press, broadcasting, etc, emerging media: mainly refers to the network media. With the acceleration of the global network process, the defects of traditional media are gradually supplemented and replaced by the network news media. In the choice of communication mode, enterprises should pay attention to the choice of communication space and time, which can be used to enhance the influence of brand culture by means of unexpected events, public events, focus events, focal figures and charitable activities. Such as after Wenchuan earthquake, the Eral company play its own advantages, through donations to donate clothes to disaster areas of the wild, but also successfully publicized the company's life-loving brand culture. The route of brand culture can be summed up as the owner of the brand, the main disseminator of the brand culture, the audience is the majority of consumers, or a specific consumer group of a product. Quality, function, price, market space, external embodiment, time accumulation and representative figures are the most important factors of brand culture. Enterprises should start with the promotion and consolidation of these elements, and through the selection of effective channels of communication. Traditional media, networks, emergencies, public events, focus events, focus on people and charitable activities, vigorously promote their brand culture achieve the effective spread of brand culture, so that people in the purchase of goods at the same time feel the influence of brand culture.

\section{ANALYSIS ON MARKETING STRATEGY OF ERAL COMPANY BASED ON INTERNET THINKING}

With the continuous development of the company's business, Eral company adopted the Internet thinking marketing and brand communication to the down jacket market has brought unprecedented impact. The company opened up a new marketing road. As mentioned above, the problems behind Alley are not to be underestimated. In the increasingly fierce competition in the down jacket market, Eral future brand communication should be under the guidance of Internet thinking, moderate hunger marketing, avoid excessive expectations; Combine traditional media, improve quality and service; Pay attention to the construction of brand culture, set up brand promotion department; Integration of Cross-border thinking, to create extended products, in order to achieve better brand communication effect.

\section{A. Moderate hunger marketing, avoid excessive expectations}

Hunger marketing is very effective in the early stages of product sales. But the period of using hunger marketing too long may cause consumers boring and the mood of resistance. According to Liu Jieke, a famous marketing expert, the marketing three-dimensional theory in "The Theory of Innovation Rhythm" the high hanging consumer's appetite will consume some people's patience. In order to ensure the balance between supply and demand, Eral company must improve the marketing practices of hunger, optimize and improve the supply chain of products, strengthen communication with manufacturers, combine technical innovation, and form a stable relationship of win-win cooperation.

\section{B. Combine with traditional media to improve quality and service}

As the process of mobile Internet is greatly advanced, many brands have set up their own online sales platform. In the future development of the company, we must keep up with the pace of the times, make full use of new social media, through micro-video advertising film, but also the use of micro-vision platform to hold various brand design competitions and other selection activities to attract the audience's attention. While using social media, we should pay more attention to the propaganda function of traditional media in the three or fourline city. With the traditional media platform, television, radio, newspapers and other traditional media advertising to attract the three or four-line potential consumers desire to buy. Combined with new social media with traditional media to carry out multi-channel product marketing. In the future development of the company should expand sales channels, online sales on the basis of the establishment of entity sales shop. Developing and extending products to meet the needs of consumers at different levels in different cities.

Having the internet thinking of the marketing way is important. The enterprises get customer recognition, affirmation and praise, the most fundament are quality of products and services. As a manufacturer must establish a "user-centric" corporate culture from market positioning, product development, production sales and even after-sale service throughout the value chain. Commercial value must be based on user value. Eral in the production of products, should pay attention to the quality of products and after-sales service. This company sets up a special quality inspection department and strict inspects of each piece sold down jacket. The company perfects down after-sales service. At the same time, the company actively cooperates with the relevant departments to investigate the fake authorized down jacket sales shop and ensure that users can get quality products and services. 


\section{Pay attention to brand culture construction, set up brand promotion department}

With the continuous progress of technology, if enterprises want to be in the fierce competition in the invincible position, they must pay attention to the construction of brand culture. The construction of brand culture can not only promote the sales of products, but also facilitate the extension of products, so that consumers will brand awareness and Lenovo to the extension of product migration. At the same time, it can enhance the attractiveness of enterprises, raise funds, attract collaborators, get the products required by the hardware suppliers to actively support and cooperate to protect the stability of the supply chain of enterprises. Eral Company in the future development should pay attention to the company brand culture construction, use the brand study method and study the brand culture.

\section{Integrate cross-border thinking and extension products}

The development of the internet has changed the rules of many traditional industries. The boundaries of industries such as retailing, manufacturing, finance and media are becoming blurred. Traditional enterprises can use the internet thinking and their own technical advantages, thus quietly changing the traditional industry rules. This is based on the Internet technology advances in the impact of cross-border thinking of industrial development. Eral Company every year will introduce fashionable new products, at the same time by virtue of their own advantages, outsourcing production, logistics and other links to enhance their core competitiveness.

In the near future, more and more enterprises will focus on the internet thinking. In the comprehensive Internet thinkdimensional guidance, the enterprises pay attention to the content and process management of brand communication, such as the integrated marketing of the user's thinking, the accurate decision of the data thinking, the extension of the trans-boundary thinking, the fast and convenient of the vermicelli thinking, the promotion of the quality service, the construction of the brand culture, etc.

\section{REFERENCES}

[1] Phillip Kotler:Marketing Management[M].Printice-hall.2004.

[2] Kevin Kne Kller, Srategie Brand Mnagement,1998 by Pentiee Hall.Inc.

[3] Ries and Tourt.A modl for predictive measurements of adbertising effectiveness [J]jounal of marketing.2010 (10).

[4] Aaker, D.A.Building Strong Brands[M].NY:Free Press.1996. 